\title{
Nodulation, Growth and Soybean Yield in Response to Seed Coating and Split Application of Phosphorus ${ }^{1}$
}

\author{
Marcos Morais Soares²*, Tuneo Sediyama ${ }^{3}$, Júlio César Lima Neves ${ }^{4}$, \\ Hamilton Carvalho dos Santos Júnior ${ }^{3}$, Laércio Junio da Silva ${ }^{3}$
}

\begin{abstract}
Phosphorus is one of the most important nutrients for soybeans, but it presents a complex dynamic in the soil and can become unavailable. The split and localized application of this nutrient can be an effective approach to increase its availability. The aim of this study was to evaluate the effect of a split phosphorus dose applied to the soil and the seed coating with monobasic sodium phosphate on nodulation, growth and yield components of soybean cultivar BRS Valiosa RR. The experiment was conducted in a greenhouse in a completely randomized design in a $2 \times 5 \times 3$ factorial arrangement, i.e., coating or not the seeds; five doses of phosphorus applied to the soil; and three times of splitting phosphate fertilizer. Phosphorus content in the index leaf (IL), dry matter of shoots, roots and nodules, yield components, and plant height were evaluated. There was an increase in nodulation and growth of plants with increased levels of phosphorus applied to the soil. In smaller doses, the seed coating and the splitting of phosphorus fertilizer increased nodulation, growth and yield components of plants. Thus, the splitting of the phosphorus dose, combined with seed coating, is indicated for increasing the yield components of soybean plants.
\end{abstract}

Index terms: Glycine max, phosphorus availability, seed treatment.

\section{Nodulação, Crescimento e Rendimento de Plantas de Soja em Resposta ao Recobrimento das Sementes e Parcelamento da Adubação Fosfatada}

\begin{abstract}
RESUMO - O fósforo é um dos nutrientes mais importantes para a soja, porém apresenta uma dinâmica complexa no solo e pode tornar-se indisponível. A aplicação parcelada e localizada desse nutriente pode ser tática eficiente para aumentar sua disponibilidade. Assim, objetivou-se avaliar o efeito do parcelamento da dose de $\mathrm{P}$ aplicada ao solo e do recobrimento das sementes com fosfato de sódio monobásico na nodulação, no crescimento e nos componentes de rendimento de plantas de soja cultivar BRS Valiosa RR. O experimento foi conduzido em casa de vegetação em delineamento inteiramente casualizado, em esquema fatorial 2x5x3, ou seja, recobrimento ou não das sementes; cinco doses de $\mathrm{P}$ aplicados ao solo; e três épocas de parcelamento da adubação fosfatada. As seguintes variáveis resposta foram avaliadas: teor de $\mathrm{P}$ na folha índice, matéria seca da parte aérea, da raiz e dos nódulos, componentes de rendimento e altura de plantas. Houve incremento na nodulação e no crescimento das plantas com o aumento das doses de fósforo aplicado no solo. Nas menores doses, o recobrimento das sementes e o parcelamento da adubação fosfatada aumentaram a nodulação, o crescimento e os componentes do rendimento das plantas. Assim, o parcelamento da dose de P, aliado ao recobrimento das sementes, é indicado para aumentar os componentes de produtividade das plantas de soja.
\end{abstract}

Termos para indexação: Glycine max, disponibilidade de fósforo, tratamento de sementes.

\section{Introduction}

Phosphorus (P) is one of the most important nutrients for soybeans crops, being absorbed from 0.2 to $0.4 \mathrm{~kg} \cdot \mathrm{ha}^{-1}$. day $^{-1}$ among phenological stages V4 and R6. This nutrient participates in many metabolic processes, such as in energy transfer (adenosine triphosphate (ATP)), photosynthesis,

${ }^{1}$ Submitted on 10/11/2015. Accepted for publication on 2/1/2016

${ }^{2}$ Fundação Universidade do Tocantins, 77020-122 - Palmas, TO, Brasil.

${ }^{3}$ Departamento de Fitotecnia, Universidade Federal de Viçosa, 36570-000 Viçosa, MG, Brasil. respiration, synthesis of nucleic acids and glucose, membrane synthesis and stability (phospholipids), activation and deactivation of enzymes (Vance et al., 2003; Thavarajah et al., 2010; Rezende et al., 2005).

In Brazilian soils, total content of phosphorus ranges between 200 and $3.000 \mathrm{mg}$. $\mathrm{kg}^{-1}$. However, less than $0.1 \%$ of this total is found available in the soil solution. Some
${ }^{4}$ Departamento de Solos, Universidade Federal de Viçosa, 36570-000 Viçosa, MG, Brasil.

*Corresponding author < agromms@yahoo.com.br> 
Latosols of the cerrado can adsorb more than $2 \mathrm{~g} \cdot \mathrm{dm}^{-3}$ of phosphorus, a figure that equivalent to $4,000 \mathrm{~kg} \cdot \mathrm{ha}^{-1}$ of phosphorus, built from 0 to $20 \mathrm{~cm}$ deep. One year after the application of single superphosphate (SSP) in four soils, $58 \%$ of phosphorus applied were available, $38 \%$ after two years and 20\% after three years (Ker et al., 1996). Phosphorus becomes unavailable due to the rapid formation of insoluble complexes with cations, especially $\mathrm{Al}$ and $\mathrm{Fe}$ in acidic conditions (Shafqat and Pierzynski, 2013; Rolim Neto et al., 2004).

To reduce the portion of phosphorus dose applied that is adsorbed, one option is to increase the concentration of the nutrient in a given volume of soil by means of its location, so that the total volume of fertilized soil, in contact with phosphorus applied, is reduced (Büll et al., 2004). However, the location can reduce the root system growth and cause deficiency of elements such as $\mathrm{Fe}, \mathrm{Cu}$ and $\mathrm{N}$, which have an absorption that is dependent on the availability of phosphorus (Aquino et al., 2011).

With the application of phosphate fertilizers in a localized way, there is greater initial availability of phosphorus for the seedlings in development, by placing it in a position available for the still reduced root system of these seedlings, besides reducing phosphorus retention to soil colloids (Lopes, 2001).

The localized application of phosphate fertilizers can be done by coating soybean seeds with phosphorus, which can contribute to increased productivity, depending on the phosphorus sources and doses used. Thus, the use of soybean seeds coated with phosphorus, in the form of phytic acid (known as inositol hexakisphosphate (IP6), inositol polyphosphate, or phytate when in salt form) (21 g. $\mathrm{kg}^{-1}$ of seeds) increased soybean yield in $14 \%$ in the total mass of grains (Peske et al., 2009). Besides, Soares et al. (2014) have concluded that soybean seed coating with monosodium phosphate (also known as anhydrous monobasic sodium phosphate and sodium dihydrogen phosphate) (MSP)) (7.0 g. $\mathrm{kg}^{-1}$ of seeds) provided an increase in nodulation and plants growth for the soil condition with less phosphorus available.

In addition to the localized application, the split application of phosphorus can help reduce phosphorus fixation to the soil. For this, the supply of a sufficient quantity of phosphorus in seeding is required to ensure an adequate initial development, especially of the root system (Souza et al., 2007). The remainder of the dose might be applied later, in a time that is compatible with the root system development, which could reduce the amount of phosphorus set by the soil. The split application of phosphorus, by decreasing the contact time of the phosphate source with the soil, can contribute to greater recovery of the phosphorus applied. Thus, in several studies in which split application of phosphorus efficiency is evaluated, it is suggested that it provides better agronomic results (Oliveira et al., 2003; Resende et al., 2006a; 2006b; Barbosa Filho et al., 2005).

In this sense, the application of phosphorus in a localized way through coating soybean seeds, combined with the split application of phosphorus at the dose applied to the soil, can contribute to a more efficient use of this nutrient by the plant, coupled with the lower retention to the soil and finally contributing to achieving higher yields. Thus, the objective of this study was to evaluate the effect of split application of phosphorus doses in the soil and coating the seeds with phosphorus in nodulation, growth and yield components of soybean plants.

\section{Material and Methods}

The experiment was conducted in a greenhouse at the Federal University of Viçosa (UFV; Universidade Federal de Viçosa) in the city of Viçosa, state of Minas Gerais, Brazil. Soybean cultivar BRS Valiosa RR was used, which presents a specified growth habit and maturity group 8.1 with full cycle ranging from 115 to 140 days. It is indicated for Brazilian states of Goiás, the Federal District, Mato Grosso, Minas Gerais and Rondônia.

Before sowing, the seeds were treated in the following sequence: (i) With fungicides carbendazim and thiram at a dose of $200 \mathrm{~mL} .100 \mathrm{~kg}^{-1}$ of seeds; (ii) Seeds coating with monosodium phosphate (salt p.a.) diluted in deionized water at the doses of 0.0 (C1) and 7.0 (C2) g. $\mathrm{kg}^{-1}$ of seeds; (iii) After seed drying, Microxisto ${ }^{\circledR}$ peat inoculant was applied at a dose of 3.0 million cells of bacteria Bradyrhizobium japonicum per seed by means of a solution with $10 \%$ sugar water, in order to improve the adhesion of the inoculant to the seeds.

After the treatment, seeds were sown in plastic pots containing $3.0 \mathrm{dm}^{3}$ of soil classified as red-yellow Latosol with the following characteristics: $\mathrm{pH}\left(\mathrm{H}_{2} \mathrm{O}\right), 5.67$; $\mathrm{P}$ (Mehlich), $3.2 \mathrm{mg} \cdot \mathrm{dm}^{-3}$; K, $54 \mathrm{mg} \cdot \mathrm{dm}^{-3}$; Ca, Mg, Al, H+Al and CEC (cation-exchange capacity) (T), 2.2; $0.7 ; 0.5 ; 9.41$ and $12.45{\mathrm{cmolc} . \mathrm{dm}^{-3}}^{-3}$, respectively; $\mathrm{V}$ (base saturation), 24\%; OM (organic matter), 5.1 dag. $\mathrm{kg}^{-1}$; P-rem, $22.6 \mathrm{mg} . \mathrm{L}^{-1}$. Clayey textural class: clay, 49 dag. $\mathrm{kg}^{-1}$; silt, 10 dag. $\mathrm{kg}^{-1}$; fine sand, 19 dag. $\mathrm{kg}^{-1}$; coarse sand, 22 dag. $\mathrm{kg}^{-1}$.

The experiment was established in the design in random blocks with four replications in the $2 \times 5 \times 3$ factorial arrangement, being without coating (C1) or coating the

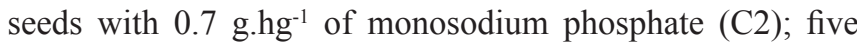


doses of phosphorus applied to the soil $(50,100,200,300$ and $400 \mathrm{mg} \cdot \mathrm{kg}^{-1}$ of soil); and three times of split application of phosphorus: Time 1 (T1) $-100 \%$ of the total dose at sowing; Time 2 (T2) $-50 \%$ of the total dose at sowing plus $50 \%$ in coating in stage V3 (second trifoliate leaf completely developed); and Time 3 (T3) $-50 \%$ of the total dose at sowing plus $25 \%$ in coating in stage V3 plus $25 \%$ in stage R1 (flowering beginning). Triple superphosphate (TSP) was used as a source of phosphorus. Topdressing was performed via two $0.5-\mathrm{cm}$ deep grooves located at five centimeters from the base of the plant.

Fertilization with potassium and micronutrients was performed at the sowing operation, based on soil analysis. Fertilization with sulfur and micronutrients was held in coating, 15 days after seedling emergence, and sulfur and micronutrients were applied via foliar feeding and fertigation on the soil surface, respectively.

Four seeds were sown in each pot, of which the two most vigorous plants were selected. Irrigation was performed daily with deionized water.

Evaluations were performed at phenological stage R2, when plants were in full bloom; in R3, at the start of pod formation; and in R8, when $95 \%$ of the pods were ripe, and consisted of the following determinations:

Phosphorus content in the index leaf (IL) - In the R2 stage, an index leaf (IL) was collected for the third fully developed trifoliate of the plant apex to the base, per plant, in each treatment. Samples of whole leaves were rinsed with deionized water, dried in an oven with forced air circulation at a temperature of $60^{\circ} \mathrm{C}$ until constant mass. Then the samples were crushed. Afterwards, phosphorus content in the leaf via nitric-perchloric digestion and quantification by mass spectrometry were determined (Malavolta et al., 1997).

In stage R3, the following evaluations were performed:

Plants shoots and roots dry matters - The plants of each treatment were placed in paper bags and kept in a thermal oven with forced air circulation set at temperature $65^{\circ} \mathrm{C}$ for 72 hours. After cooling in a desiccator, each replication was weighed on a precision scale of $0.001 \mathrm{~g}$ and the results were expressed in grams per plant.

Nodules dry matter - After the removal of the nodules from the root system, they were stored in paper bags and kept in a thermal oven with forced air circulation set at temperature $65^{\circ} \mathrm{C}$ for 72 hours. After cooling in a desiccator, each replication was weighed on a precision scale of $0.001 \mathrm{~g}$ and the results were expressed in grams per plant.

In reproductive stage $\mathrm{R} 8$, the following evaluations were performed:
Yield components - Number of pods per plant, number of seeds per plant and the total mass of seeds per plant were determined.

Plant height - Plant height of each plant was determined with a tape measure. The result was expressed as $\mathrm{cm}$ per plant.

\section{Data analysis}

The data were subjected to analysis of variance and the means for the doses used in the coating were compared using the F-test $(p<0.05)$; the means for the split application of phosphorus times were compared by the Tukey's test ( $p \leq$ $0.05)$. To compare the phosphorus doses in the soil, regression analysis was performed. The regression coefficients were tested by the t-test $(p \leq 0.05)$.

\section{Results and Discussion}

There was no significant interaction among coating treatments of seeds, phosphorus dose applied to the soil and application time. However, even in the absence of significance, all the triple interactions were unfolded in order to evaluate the individual effect of a certain treatment on the basis of the levels of the other treatments.

There was a linear increase in plant height and phosphorus content in leaves with increasing phosphorus levels in the soil (Figure 1). In general, the lowest phosphorus levels in leaves were obtained for the treatments in which the doses of phosphorus were applied in full at sowing (TI), together or not with seeds coating, with an average increase of 0.0003 dag. $\mathrm{kg}^{-1}$ of phosphorus in the seeds for each mg. $\mathrm{kg}^{-1}$ of phosphorus in the soil (Figure 1).

In general, comparing the split application of phosphorus and seeds coating in each dose of phosphorus in the soil, there was no difference in plant height (Table 1). Regarding phosphorus content in the index leaf (IL) (Table 2), only in the higher doses of phosphorus in the soil an effect of application time and coating was observed. At the highest dose of phosphorus ( $\left.400 \mathrm{mg} \cdot \mathrm{kg}^{-1}\right)$, the application of $50 \%$ of the dose at sowing and $50 \%$ in stage V3 provided a higher accumulation of phosphorus in the index leaf (IL), both from the seeds without coating, as from the seeds coated with phosphorus. In the lowest doses of phosphorus in the soil, foliar content of this nutrient was below the concentration range considered ideal, which is from 0.22 to $0.34 \mathrm{mg} \cdot \mathrm{dag}^{-1}$ of phosphorus (Broch and Ranno, 2008). Therefore, phosphorus level in the soil for these doses was insufficient for absorption and proper translocation of the nutrient by the plant to occur. 

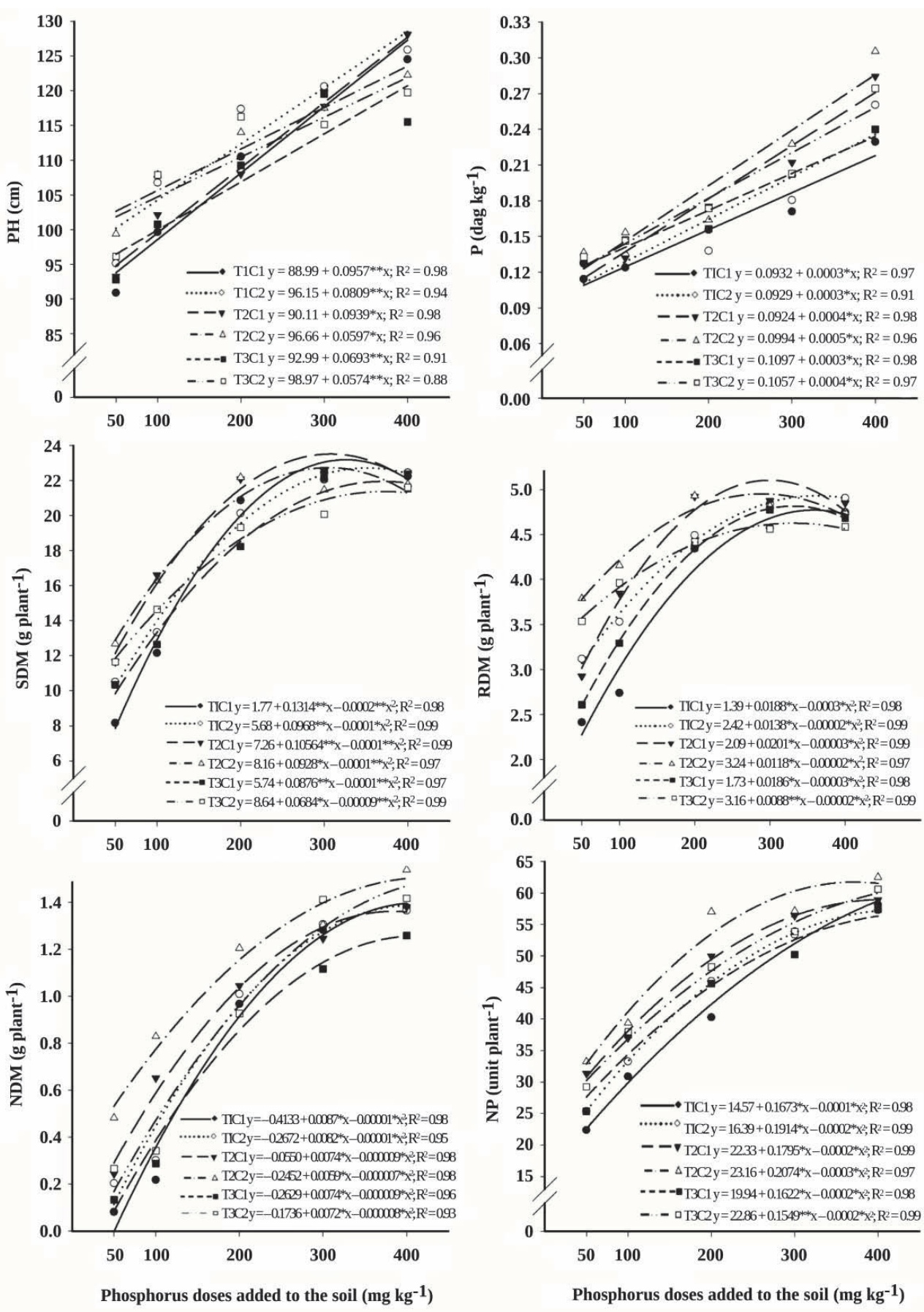

Figure 1. Plants height (PH), index leaf (IL) phosphorus content (P), shoots dry matter (SDM), roots dry matter (RDM), nodules dry matter (NDM) and number of pods (NP) per soybean plant of cultivar BRS Valiosa RR due to the phosphorus doses in the soil, the seeds coating (C1: without; $\mathrm{C} 2$ : coating with $7.0 \mathrm{~g} \cdot \mathrm{kg}^{-1}$ of monosodium phosphate) and split application of phosphorus times (T1: 100\% of the total dose at sowing; T2: 50\% of the total dose at sowing plus 50\% in coating in stage V3; T3: $50 \%$ of the total dose at sowing plus $25 \%$ in coating in stage V3 plus $25 \%$ in stage $\mathrm{C} 1$ ). 
Table 1. Plants height (cm) of soybean plant of cultivar BRS Valiosa RR due to the phosphorus doses applied in the soil, seeds coating and split application of phosphorus times.

\begin{tabular}{|c|c|c|c|c|c|c|}
\hline \multirow{3}{*}{$\begin{array}{l}\text { Split application } \\
\text { of phosphorus }\end{array}$} & \multicolumn{6}{|c|}{ Doses of phosphorus (mg.kg-1 of phosphorus in the soil) } \\
\hline & \multicolumn{2}{|c|}{50} & \multicolumn{2}{|c|}{100} & \multicolumn{2}{|c|}{200} \\
\hline & $\mathrm{C} 1$ & $\mathrm{C} 2$ & $\mathrm{C} 1$ & $\mathrm{C} 2$ & $\mathrm{C} 1$ & $\mathrm{C} 2$ \\
\hline T1 & $90.88 \mathrm{Aa}$ & $95.13 \mathrm{Aa}$ & $99.63 \mathrm{Aa}$ & $106.75 \mathrm{Aa}$ & $110.50 \mathrm{Aa}$ & $117.38 \mathrm{Aa}$ \\
\hline $\mathrm{T} 2$ & $93.25 \mathrm{Aa}$ & $99.38 \mathrm{Aa}$ & $102.13 \mathrm{Aa}$ & $107.88 \mathrm{Aa}$ & $108.00 \mathrm{Aa}$ & $114.00 \mathrm{Aa}$ \\
\hline \multirow[t]{3}{*}{$\mathrm{T} 3$} & $92.75 \mathrm{Aa}$ & $96.13 \mathrm{Aa}$ & $100.75 \mathrm{Aa}$ & $107.88 \mathrm{Aa}$ & $109.25 \mathrm{Aa}$ & $116.25 \mathrm{Aa}$ \\
\hline & \multicolumn{2}{|c|}{300} & \multicolumn{2}{|c|}{400} & & \\
\hline & $\mathrm{C} 1$ & $\mathrm{C} 2$ & $\mathrm{C} 1$ & $\mathrm{C} 2$ & & \\
\hline $\mathrm{T} 1$ & $120.00 \mathrm{Aa}$ & $120.63 \mathrm{Aa}$ & $124.50 \mathrm{ABa}$ & $125.88 \mathrm{Aa}$ & & \\
\hline $\mathrm{T} 2$ & $117.75 \mathrm{Aa}$ & $117.50 \mathrm{Aa}$ & $128.12 \mathrm{Aa}$ & $122.25 \mathrm{Aa}$ & & \\
\hline $\mathrm{T} 3$ & $119.50 \mathrm{Aa}$ & $115.13 \mathrm{Aa}$ & $115.50 \mathrm{Ba}$ & $119.75 \mathrm{Aa}$ & & \\
\hline
\end{tabular}

Split application of phosphorus T1: $100 \%$ of the total dose at sowing; T2: $50 \%$ of the total dose at sowing plus $50 \%$ in coating in stage V3; T3: $50 \%$ of the total dose at sowing plus $25 \%$ in coating in stage $\mathrm{V} 3$ plus $25 \%$ in stage $\mathrm{C} 1$.

Seed coating: $\mathrm{C} 1$ - without coating and $\mathrm{C} 2$ - with coating.

Within each phosphorus dose, the means followed by the same letter, lowercase in the row and uppercase in the column do not differ by the F-test $(P \leq 0.05)$ and Tukey's test $(P \leq 0.05)$, respectively.

Table 2. Phosphorus content in the index leaf (IL) (dag.plant ${ }^{-1}$ ) of soybean plants of cultivar BRS Valiosa RR due to the phosphorus doses applied in the soil, seeds coating and split application of phosphorus times.

\begin{tabular}{|c|c|c|c|c|c|c|}
\hline \multirow{3}{*}{$\begin{array}{l}\text { Split application } \\
\text { of phosphorus }\end{array}$} & \multicolumn{6}{|c|}{ Doses of phosphorus (mg.kg-1 of phosphorus in the soil) } \\
\hline & \multicolumn{2}{|c|}{50} & \multicolumn{2}{|c|}{100} & \multicolumn{2}{|c|}{200} \\
\hline & $\mathrm{C} 1$ & $\mathrm{C} 2$ & $\mathrm{C} 1$ & $\mathrm{C} 2$ & $\mathrm{C} 1$ & $\mathrm{C} 2$ \\
\hline T1 & $0.11 \mathrm{Aa}$ & $0.13 \mathrm{Aa}$ & $0.12 \mathrm{Aa}$ & $0.13 \mathrm{Aa}$ & $0.16 \mathrm{Aa}$ & $0.15 \mathrm{Aa}$ \\
\hline $\mathrm{T} 2$ & $0.13 \mathrm{Aa}$ & $0.14 \mathrm{Aa}$ & $0.13 \mathrm{Aa}$ & $0.15 \mathrm{Aa}$ & $0.18 \mathrm{Aa}$ & $0.16 \mathrm{Aa}$ \\
\hline \multirow[t]{3}{*}{$\mathrm{T} 3$} & $0.13 \mathrm{Aa}$ & $0.13 \mathrm{Aa}$ & $0.15 \mathrm{Aa}$ & $0.15 \mathrm{Aa}$ & $0.16 \mathrm{Aa}$ & $0.17 \mathrm{Aa}$ \\
\hline & \multicolumn{2}{|c|}{300} & \multicolumn{2}{|c|}{400} & & \\
\hline & $\mathrm{C} 1$ & $\mathrm{C} 2$ & $\mathrm{C} 1$ & $\mathrm{C} 2$ & & \\
\hline $\mathrm{T} 1$ & $0.18 \mathrm{Aa}$ & $0.18 \mathrm{Ba}$ & $0.23 \mathrm{Bb}$ & $0.26 \mathrm{Ba}$ & & \\
\hline $\mathrm{T} 2$ & $0.21 \mathrm{Aa}$ & $0.23 \mathrm{Aa}$ & $0.28 \mathrm{Aa}$ & $0.31 \mathrm{Aa}$ & & \\
\hline $\mathrm{T} 3$ & $0.20 \mathrm{Aa}$ & $0.20 \mathrm{Ba}$ & $0.24 \mathrm{Bb}$ & $0.27 \mathrm{Ba}$ & & \\
\hline
\end{tabular}

Split application of phosphorus T1: $100 \%$ of the total dose at sowing; T2: $50 \%$ of the total dose at sowing plus $50 \%$ in coating in stage V3; T3: $50 \%$ of the tota dose at sowing plus $25 \%$ in coating in stage V3 plus $25 \%$ in stage $\mathrm{C} 1$.

Seed coating: $\mathrm{C} 1$ - without coating and $\mathrm{C} 2$ - with coating.

Within each phosphorus dose, the means followed by the same letter, lowercase in the row and uppercase in the column, do not differ by the F-test $(P \leq 0.05)$ and Tukey's test $(P \leq 0.05)$, respectively.

The results obtained in this study are in agreement with those obtained by Trigo et al. (1997) who, when comparing different phosphorus levels in the seeds and phosphorus doses in the soil, have found that the higher the phosphorus content in the seeds and in the soil, the taller the soybean plants.

In relation to the dose split application of phosphorus and seeds coating with phosphorus, these had no effect on plant height. The split application of phosphorus has not always presented good results, as reported by Aquino et al. (2011), who found that fertilizer split application has not increased phosphorus absorption and cotton seed yield in dryland or flooded farming systems.

Increased levels of phosphorus in the soil and seed have caused increases in the amount of phosphorus in shoots, probably because they enabled greater translocation. An adequate supply of phosphorus promotes root growth and increases the amount of nutrient absorbed (Souza et al., 2007; Nico et al., 2012).

In Figure 1, a quadratic trend is observed for the data of shoots dry matter (SDM), roots dry matter (RDM) and nodules dry matter (NDM), due to increased levels of phosphorus in the soil. Maximum dry matter accumulation in shoots, roots and nodules was obtained with the split application of phosphorus in two seasons at doses above $335 \mathrm{mg} \cdot \mathrm{kg}^{-1}$ of soil. Unlike the dry matter of shoots and roots, greater dry matter of nodules was obtained for seeds receiving coating. 
There was an effect of split application of phosphorus in SDM only in smaller doses of phosphorus, and the highest values were obtained for the application of $50 \%$ of the dose at sowing and $50 \%$ in V3 (T2) in the uncoated treatment (Table 3). Similar results were obtained for RDM (Table 4) and for NDM (Table 5), and in doses of 50, 100 and $200 \mathrm{mg} \mathrm{kg}^{-1}$, the highest values were obtained for the T2 split application of phosphorus, both for seeds receiving coating and for those which did not receive it.

Table 3. Shoots dry matter (g.plant ${ }^{-1}$ ) of soybean plants of cultivar BRS Valiosa RR due to the phosphorus doses applied in the soil, seeds coating and split application of phosphorus times.

\begin{tabular}{|c|c|c|c|c|c|c|}
\hline \multirow{3}{*}{$\begin{array}{l}\text { Split application } \\
\text { of phosphorus }\end{array}$} & \multicolumn{6}{|c|}{ Doses of phosphorus (mg.kg-1 of phosphorus in the soil) } \\
\hline & \multicolumn{2}{|c|}{50} & \multicolumn{2}{|c|}{100} & \multicolumn{2}{|c|}{200} \\
\hline & $\mathrm{C} 1$ & $\mathrm{C} 2$ & $\mathrm{C} 1$ & $\mathrm{C} 2$ & $\mathrm{C} 1$ & $\mathrm{C} 2$ \\
\hline $\mathrm{T} 1$ & $8.16 \mathrm{Ba}$ & $10.50 \mathrm{Aa}$ & $12.15 \mathrm{Ba}$ & $13.33 \mathrm{Ba}$ & $20.80 \mathrm{Ba}$ & $20.12 \mathrm{ABa}$ \\
\hline $\mathrm{T} 2$ & $11.65 \mathrm{Aa}$ & $12.69 \mathrm{Aa}$ & $16.60 \mathrm{Aa}$ & $16.28 \mathrm{Aa}$ & $22.08 \mathrm{Aa}$ & $22.18 \mathrm{Aa}$ \\
\hline \multirow[t]{3}{*}{$\mathrm{T} 3$} & $10.34 \mathrm{ABa}$ & $11.64 \mathrm{Aa}$ & $12.64 \mathrm{Ba}$ & $14.64 \mathrm{ABa}$ & $18.32 \mathrm{Ba}$ & $19.23 \mathrm{Ba}$ \\
\hline & \multicolumn{2}{|c|}{300} & \multicolumn{2}{|c|}{400} & & \\
\hline & $\mathrm{C} 1$ & $\mathrm{C} 2$ & $\mathrm{C} 1$ & $\mathrm{C} 2$ & & \\
\hline $\mathrm{T} 1$ & $22.46 \mathrm{Aa}$ & $22.03 \mathrm{Aa}$ & $22.23 \mathrm{Aa}$ & $22.45 \mathrm{Aa}$ & & \\
\hline $\mathrm{T} 2$ & $22.53 \mathrm{Aa}$ & $21.47 \mathrm{Aa}$ & $22.43 \mathrm{Aa}$ & $21.78 \mathrm{Aa}$ & & \\
\hline $\mathrm{T} 3$ & $22.12 \mathrm{Aa}$ & $20.06 \mathrm{Aa}$ & $21.52 \mathrm{Aa}$ & $21.59 \mathrm{Aa}$ & & \\
\hline
\end{tabular}

Split application of phosphorus T1: $100 \%$ of the total dose at sowing; T2: $50 \%$ of the total dose at sowing plus 50\% in coating in stage V3; T3: $50 \%$ of the tota dose at sowing plus $25 \%$ in coating in stage V3 plus $25 \%$ in stage $\mathrm{C} 1$.

Seed coating: $\mathrm{C} 1$ - without coating and $\mathrm{C} 2$ - with coating.

Within each phosphorus dose, the means followed by the same letter, lowercase in the row and uppercase in the column, do not differ by the F-test $(P \leq 0.05)$ and Tukey's test $(P \leq 0.05)$, respectively.

Table 4. Roots dry matter (g.plant ${ }^{-1}$ ) of soybean plants of cultivar BRS Valiosa RR due to the phosphorus doses applied in the soil, seeds coating and split application of phosphorus times.

\begin{tabular}{|c|c|c|c|c|c|c|}
\hline \multirow{3}{*}{$\begin{array}{l}\text { Split application } \\
\text { of phosphorus }\end{array}$} & \multicolumn{6}{|c|}{ Doses of phosphorus (mg.kg-1 of phosphorus in the soil) } \\
\hline & \multicolumn{2}{|c|}{50} & \multicolumn{2}{|c|}{100} & \multicolumn{2}{|c|}{200} \\
\hline & $\mathrm{C} 1$ & $\mathrm{C} 2$ & $\mathrm{C} 1$ & $\mathrm{C} 2$ & $\mathrm{C} 1$ & $\mathrm{C} 2$ \\
\hline T1 & $2.41 \mathrm{Bb}$ & $3.12 \mathrm{Ba}$ & $2.74 \mathrm{Rb}$ & $3.53 \mathrm{Ba}$ & $4.34 \mathrm{Ba}$ & $4.49 \mathrm{Ba}$ \\
\hline $\mathrm{T} 2$ & $2.92 \mathrm{Ab}$ & $3.79 \mathrm{Aa}$ & $3.85 \mathrm{Aa}$ & 4.15 Aa & $4.92 \mathrm{Aa}$ & $4.93 \mathrm{Aa}$ \\
\hline \multirow[t]{3}{*}{$\mathrm{T} 3$} & $2.61 \mathrm{ABb}$ & $3.53 \mathrm{ABa}$ & $3.29 \mathrm{Bb}$ & $3.96 \mathrm{Aba}$ & $4.36 \mathrm{Ba}$ & $4.42 \mathrm{Ba}$ \\
\hline & \multicolumn{2}{|c|}{300} & \multicolumn{2}{|c|}{400} & & \\
\hline & $\mathrm{C} 1$ & $\mathrm{C} 2$ & $\mathrm{C} 1$ & $\mathrm{C} 2$ & & \\
\hline T1 & $4.57 \mathrm{Aa}$ & $4.84 \mathrm{Aa}$ & $4.75 \mathrm{Aa}$ & $4.90 \mathrm{Aa}$ & & \\
\hline $\mathrm{T} 2$ & $4.87 \mathrm{Aa}$ & $4.82 \mathrm{Aa}$ & $4.85 \mathrm{Aa}$ & $4.75 \mathrm{Aa}$ & & \\
\hline $\mathrm{T} 3$ & $4.78 \mathrm{Aa}$ & $4.56 \mathrm{Aa}$ & $4.68 \mathrm{Aa}$ & $4.58 \mathrm{Aa}$ & & \\
\hline
\end{tabular}

Split application of phosphorus T1: $100 \%$ of the total dose at sowing; T2: $50 \%$ of the total dose at sowing plus $50 \%$ in coating in stage V3; T3: $50 \%$ of the total dose at sowing plus $25 \%$ in coating in stage V 3 plus $25 \%$ in stage $\mathrm{C} 1$.

Seed coating: $\mathrm{C} 1$ - without coating and $\mathrm{C} 2$ - with coating.

Within each phosphorus dose, the means followed by the same letter, lowercase in the row and uppercase in the column, do not differ by the F-test $(P \leq 0.05)$ and Tukey's test $(P \leq 0.05)$, respectively.

According to Meis et al. (2003), an increase of phosphorus in the seeds was responsible for the significant increase in dry matter of the shoots of soybean plants at 21 days after emergence due to the increased translocation of nutrients to the shoots, which contributed to an increased formation of biomass. In addition, phosphorus promotes rapid formation and growth of roots, resulting in their greater development. This is confirmed by other authors, such as Lopes (2001), who has found that seeds coating with phosphorus puts it in position available to the root system still reduced in the seedlings in early growth.

Phosphorus is very important in biological nitrogen fixation, as the reduction of atmospheric $\mathrm{N}_{2}$ into ammonia, which occurs in bacteroids, and the assimilation of ammonium by the plant are energy consuming processes, dependent on the availability of ATP. Therefore, phosphorus acts in the growth and operation of nodules (Almeida et al., 2006). In 
this sense, phosphorus availability in the soil accounted for the increase and change in the shape of nodules in Trifolium arvense, as well it increased the efficiency to fix nitrogen $\left(\mathrm{N}_{2}\right)$ of this plant (Chmelikova and Hejcman, 2012), which is in accordance with the data obtained in this study for NDM.

In the lowest dose of phosphorus $\left(50 \mathrm{mg} . \mathrm{kg}^{-1}\right)$ there was a higher formation of nodules in the plants from seeds receiving coating (Table 5). Thus, the greater nodulation of the plants may be related to the fact of greater increase of phosphorus in seeds promoting faster and greater root system development, resulting in increased nodulation (Teixeira et al., 1999). This was also observed in other studies (Pacheco et al., 2012).

Table 5. Nodules dry matter (g.plant ${ }^{-1}$ ) of soybean plants of cultivar BRS Valiosa RR due to the phosphorus doses applied in the soil, seeds coating and split application of phosphorus times.

\begin{tabular}{|c|c|c|c|c|c|c|}
\hline \multirow{3}{*}{$\begin{array}{l}\text { Split application } \\
\text { of phosphorus }\end{array}$} & \multicolumn{6}{|c|}{ Doses of phosphorus (mg.kg ${ }^{-1}$ of phosphorus in the soil) } \\
\hline & \multicolumn{2}{|c|}{50} & \multicolumn{2}{|c|}{100} & \multicolumn{2}{|c|}{200} \\
\hline & $\mathrm{C} 1$ & $\mathrm{C} 2$ & $\mathrm{C} 1$ & $\mathrm{C} 2$ & $\mathrm{C} 1$ & $\mathrm{C} 2$ \\
\hline T1 & $0.081 \mathrm{Bb}$ & $0.234 \mathrm{Ba}$ & $0.258 \mathrm{Ba}$ & $0.302 \mathrm{Ba}$ & $0.968 \mathrm{Aa}$ & $1.009 \mathrm{Ba}$ \\
\hline $\mathrm{T} 2$ & $0.244 \mathrm{Ab}$ & $0.482 \mathrm{Aa}$ & $0.652 \mathrm{Ab}$ & $0.829 \mathrm{Aa}$ & $1.045 \mathrm{Ab}$ & $1.205 \mathrm{Aa}$ \\
\hline \multirow[t]{3}{*}{$\mathrm{T} 3$} & $0.134 \mathrm{ABb}$ & $0.265 \mathrm{Ba}$ & $0.288 \mathrm{Ba}$ & $0.342 \mathrm{Ba}$ & $0.926 \mathrm{Aa}$ & $0.924 \mathrm{Ba}$ \\
\hline & \multicolumn{2}{|c|}{300} & \multicolumn{2}{|c|}{400} & & \\
\hline & $\mathrm{C} 1$ & $\mathrm{C} 2$ & $\mathrm{C} 1$ & $\mathrm{C} 2$ & & \\
\hline T1 & $1.282 \mathrm{Aa}$ & $1.307 \mathrm{Aa}$ & $1.377 \mathrm{Aa}$ & $1.365 \mathrm{Aa}$ & & \\
\hline $\mathrm{T} 2$ & $1.246 \mathrm{Aa}$ & $1.305 \mathrm{Aa}$ & $1.381 \mathrm{Ab}$ & $1.539 \mathrm{Ba}$ & & \\
\hline $\mathrm{T} 3$ & $1.117 \mathrm{Ab}$ & $1.435 \mathrm{Aa}$ & $1.259 \mathrm{Ab}$ & $1.418 \mathrm{Aa}$ & & \\
\hline
\end{tabular}

Split application of phosphorus T1: $100 \%$ of the total dose at sowing; T2: $50 \%$ of the total dose at sowing plus 50\% in coating in stage V3; T3: $50 \%$ of the total dose at sowing plus $25 \%$ in coating in stage V3 plus $25 \%$ in stage $\mathrm{C} 1$.

Seed coating: $\mathrm{C} 1$ - without coating and $\mathrm{C} 2$ - with coating.

Within each phosphorus dose, the means followed by the same letter, lowercase in the row and uppercase in the column, do not differ by the F-test $(P \leq 0.05)$ and Tukey's test $(P \leq 0.05)$, respectively.

There was also an increase in the number of pods (NP) (Figure 1) and in the number of seeds per plant (NSP) (Figure 2) as the phosphorus dose in the soil was increased. In general, higher NP and NSP were observed for both the seeds that received and those that did not receive coating in treatment $\mathrm{T} 2(50 \%$ of the dose at sowing and $50 \%$ in stage V3) (Table 6). Similar results were obtained by Peske et al. (2009), who have found an increase in the number of soybean plant seeds by increasing phosphorus in the soil and seeds coating by using phytic acid as phosphorus source.
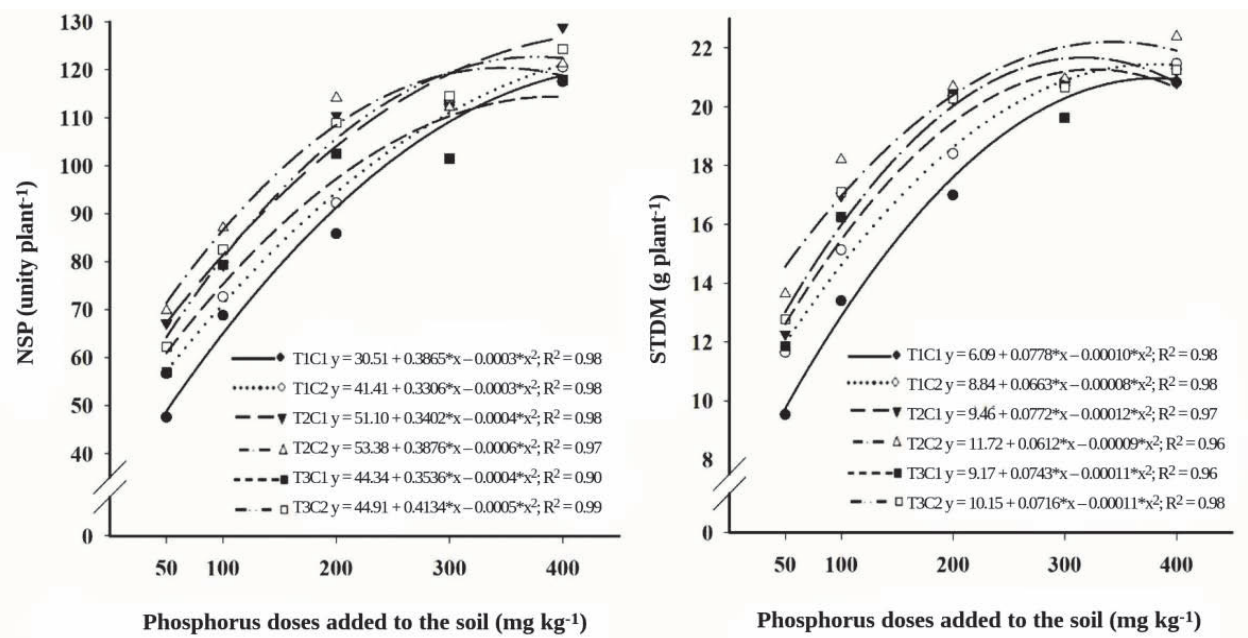

Figure 2. Number of seeds per plant (NSP) and seeds total dry matter (STDM) per soybean plant of cultivar BRS Valiosa RR due to the phosphorus doses in the soil, the seeds coating $\left(\mathrm{C} 1\right.$ : without; $\mathrm{C} 2$ : coating with $7.0 \mathrm{~g} \cdot \mathrm{kg}^{-1}$ of monosodium phosphate $)$ and split application of phosphorus times (T1: $100 \%$ of the total dose at sowing; T2: $50 \%$ of the total dose at sowing plus 50\% in coating in stage V3; T3: $50 \%$ of the total dose at sowing plus $25 \%$ in coating in stage V3 plus $25 \%$ in stage $\mathrm{C} 1$ ). 
Table 6. Number of pods per soybean plant of cultivar BRS Valiosa RR due to the phosphorus doses applied in the soil, seeds coating and split application of phosphorus times.

\begin{tabular}{|c|c|c|c|c|c|c|}
\hline \multirow{3}{*}{$\begin{array}{l}\text { Split application } \\
\text { of phosphorus }\end{array}$} & \multicolumn{6}{|c|}{ Doses of phosphorus (mg. $\mathrm{kg}^{-1}$ of phosphorus in the soil) } \\
\hline & \multicolumn{2}{|c|}{50} & \multicolumn{2}{|c|}{100} & \multicolumn{2}{|c|}{200} \\
\hline & $\mathrm{C} 1$ & $\mathrm{C} 2$ & $\mathrm{C} 1$ & $\mathrm{C} 2$ & $\mathrm{C} 1$ & $\mathrm{C} 2$ \\
\hline T1 & $22.37 \mathrm{Ba}$ & $25.37 \mathrm{Ba}$ & $30.87 \mathrm{Ba}$ & $33.25 \mathrm{Ba}$ & $40.25 \mathrm{Bb}$ & $46.24 \mathrm{Ba}$ \\
\hline $\mathrm{T} 2$ & $31.37 \mathrm{Aa}$ & $33.24 \mathrm{Aa}$ & $37.25 \mathrm{Aa}$ & $39.36 \mathrm{Aa}$ & $50.00 \mathrm{Ab}$ & $57.00 \mathrm{Aa}$ \\
\hline \multirow[t]{3}{*}{$\mathrm{T} 3$} & $25.37 \mathrm{Ba}$ & $29.25 \mathrm{ABa}$ & $37.50 \mathrm{Aa}$ & $38.00 \mathrm{ABa}$ & $45.62 \mathrm{ABa}$ & $48.25 \mathrm{Ba}$ \\
\hline & \multicolumn{2}{|c|}{300} & \multicolumn{2}{|c|}{400} & & \\
\hline & $\mathrm{C} 1$ & $\mathrm{C} 2$ & $\mathrm{C} 1$ & $\mathrm{C} 2$ & & \\
\hline T1 & $53.87 \mathrm{ABa}$ & $53.37 \mathrm{Aa}$ & $58.13 \mathrm{Aa}$ & $57.25 \mathrm{Ba}$ & & \\
\hline $\mathrm{T} 2$ & $56.37 \mathrm{Aa}$ & $57.12 \mathrm{Aa}$ & $58.87 \mathrm{Aa}$ & $62.50 \mathrm{Aa}$ & & \\
\hline T3 & $50.25 \mathrm{Ba}$ & $53.88 \mathrm{Aa}$ & $57.38 \mathrm{Aa}$ & $60.57 \mathrm{ABa}$ & & \\
\hline
\end{tabular}

Split application of phosphorus T1: $100 \%$ of the total dose at sowing; T2: $50 \%$ of the total dose at sowing plus $50 \%$ in coating in stage V3; T3: $50 \%$ of the total dose at sowing plus $25 \%$ in coating in stage V 3 plus $25 \%$ in stage $\mathrm{C} 1$.

Seed coating: $\mathrm{C} 1$ - without coating and $\mathrm{C} 2$ - with coating.

Within each phosphorus dose, the means followed by the same letter, lowercase in the row and uppercase in the column, do not differ by the F-test $(P \leq 0.05)$ and Tukey's test $(P \leq 0.05)$, respectively.

Generally, under conditions of low availability of phosphorus, there is a reduction in the number of pods per plant and the number of seeds per pod and seed mass is not reduced because plants respond to phosphorus deficiency by adaptations that maximize the likelihood of producing viable seeds (Grant et al., 2001).
Therefore, in the present study, split application of phosphorus was effective in increasing the availability of phosphorus for plants, especially in smaller doses, which contributed to the increased formation of pods and greater number of seeds per plant, as seen in Figures 1 and 2 and in Tables 6 and 7.

Table 7. Number of seeds per soybean plant of cultivar BRS Valiosa RR due to the phosphorus doses applied in the soil, seeds coating and split application of phosphorus times.

\begin{tabular}{|c|c|c|c|c|c|c|}
\hline \multirow{3}{*}{$\begin{array}{l}\text { Split application } \\
\text { of phosphorus }\end{array}$} & \multicolumn{6}{|c|}{ Doses of phosphorus (mg.kg-1 of phosphorus in the soil) } \\
\hline & \multicolumn{2}{|c|}{50} & \multicolumn{2}{|c|}{100} & \multicolumn{2}{|c|}{200} \\
\hline & $\mathrm{C} 1$ & $\mathrm{C} 2$ & $\mathrm{C} 1$ & $\mathrm{C} 2$ & $\mathrm{C} 1$ & $\mathrm{C} 2$ \\
\hline T1 & $47.50 \mathrm{Ba}$ & $56.63 \mathrm{Ba}$ & $68.75 \mathrm{Ba}$ & $72.63 \mathrm{Ba}$ & $85.75 \mathrm{Ba}$ & $92.19 \mathrm{Ba}$ \\
\hline $\mathrm{T} 2$ & $67.13 \mathrm{Aa}$ & $69.75 \mathrm{Aa}$ & $79.25 \mathrm{Aa}$ & $87.00 \mathrm{Aa}$ & $110.50 \mathrm{Aa}$ & $114.13 \mathrm{Aa}$ \\
\hline \multirow[t]{3}{*}{$\mathrm{T} 3$} & $56.87 \mathrm{ABa}$ & $62.25 \mathrm{ABa}$ & $79.38 \mathrm{Aa}$ & $82.50 \mathrm{ABa}$ & $102.50 \mathrm{Aa}$ & $108.88 \mathrm{Aa}$ \\
\hline & \multicolumn{2}{|c|}{300} & \multicolumn{2}{|c|}{400} & & \\
\hline & $\mathrm{C} 1$ & $\mathrm{C} 2$ & $\mathrm{C} 1$ & $\mathrm{C} 2$ & & \\
\hline T1 & $113.50 \mathrm{Aa}$ & $112.75 \mathrm{Aa}$ & $117.50 \mathrm{Ba}$ & $120.50 \mathrm{Aa}$ & & \\
\hline $\mathrm{T} 2$ & $112.63 \mathrm{Aa}$ & $112.13 \mathrm{Aa}$ & $128.88 \mathrm{Aa}$ & $121.50 \mathrm{Aa}$ & & \\
\hline $\mathrm{T} 3$ & $101.50 \mathrm{Bb}$ & $114.50 \mathrm{Aa}$ & $117.88 \mathrm{Ba}$ & $124.25 \mathrm{Aa}$ & & \\
\hline
\end{tabular}

Split application of phosphorus T1: $100 \%$ of the total dose at sowing; T2: $50 \%$ of the total dose at sowing plus 50\% in coating in stage V3; T3: $50 \%$ of the total dose at sowing plus $25 \%$ in coating in stage V3 plus $25 \%$ in stage $\mathrm{C} 1$.

Seed coating: $\mathrm{C} 1$ - without coating and $\mathrm{C} 2$ - with coating.

Within each phosphorus dose, the means followed by the same letter, lowercase in the row and uppercase in the column, do not differ by the F-test $(P \leq 0.05)$ and Tukey's test $(P \leq 0.05)$, respectively.

A quadratic trend was observed for the total mass of seeds (STDM) data due to increasing phosphorus levels in the soil (Figure 2), and the largest maximum value (22.1 g.plant ${ }^{-1}$ ) was obtained from the seeds receiving coating (C2) and the phosphorus dose in the soil was split in two times (T2). There was no effect of coating and the split application of phosphorus on higher doses of phosphorus in the soil (300 and $400 \mathrm{mg} \cdot \mathrm{kg}^{-1}$ ), while in other doses there was a trend for larger total mass of seeds in the treatments with split application of phosphorus (T2 and T3) (Table 8). As for the seeds coating, the highest values were obtained for the seeds receiving coating when smaller doses of phosphorus were applied in the soil (50 and $100 \mathrm{mg} \cdot \mathrm{kg}^{-1}$ ). The results obtained in this study are consistent with those obtained by Peske et al. (2009), who observed an increase in the total mass of soybean grain by $14 \%$ with seed coating with phosphorus.

An adequate supply of phosphorus promotes root growth and increases the amount of nutrient absorbed 
(Souza et al., 2007; Dordas, 2009; Dorsch et al., 2003; Rose et al., 2010). Thus, in the soil condition with lower phosphorus availability, coating the seeds with phosphorous provided an increase in nodulation and growth of soybean plants (Tables 3, 4 and 5), besides higher seed mass per plant (Table 8).

Table 8. Seeds total dry matter (g.plant ${ }^{-1}$ ) of soybean plants of cultivar BRS Valiosa RR due to the phosphorus doses applied in the soil, seeds coating and split application of phosphorus times.

\begin{tabular}{|c|c|c|c|c|c|c|}
\hline \multirow{3}{*}{$\begin{array}{l}\text { Split application } \\
\text { of phosphorus }\end{array}$} & \multicolumn{6}{|c|}{ Doses of phosphorus (mg.kg-1 of phosphorus in the soil) } \\
\hline & \multicolumn{2}{|c|}{50} & \multicolumn{2}{|c|}{100} & \multicolumn{2}{|c|}{200} \\
\hline & $\mathrm{C} 1$ & $\mathrm{C} 2$ & $\mathrm{C} 1$ & $\mathrm{C} 2$ & $\mathrm{C} 1$ & $\mathrm{C} 2$ \\
\hline T1 & $9.52 \mathrm{Bb}$ & $11.64 \mathrm{Ba}$ & $13.39 \mathrm{Bb}$ & $15.12 \mathrm{Ba}$ & $16.98 \mathrm{Bb}$ & $18.39 \mathrm{Ba}$ \\
\hline $\mathrm{T} 2$ & $12.27 \mathrm{Ab}$ & $13.65 \mathrm{Aa}$ & $16.97 \mathrm{Ab}$ & $18.89 \mathrm{Aa}$ & $20.26 \mathrm{Aa}$ & $20.68 \mathrm{Aa}$ \\
\hline \multirow[t]{3}{*}{$\mathrm{T} 3$} & $11.84 \mathrm{Aa}$ & $12.77 \mathrm{ABa}$ & $16.64 \mathrm{Aa}$ & $17.10 \mathrm{Aa}$ & $20.37 \mathrm{Aa}$ & $20.29 \mathrm{Aa}$ \\
\hline & \multicolumn{2}{|c|}{300} & \multicolumn{2}{|c|}{400} & & \\
\hline & $\mathrm{C} 1$ & $\mathrm{C} 2$ & $\mathrm{C} 1$ & $\mathrm{C} 2$ & & \\
\hline T1 & $20.70 \mathrm{Aa}$ & $20.84 \mathrm{Aa}$ & $20.82 \mathrm{Aa}$ & $21.46 \mathrm{Aa}$ & & \\
\hline $\mathrm{T} 2$ & $20.74 \mathrm{Aa}$ & $20.94 \mathrm{Aa}$ & $21.20 \mathrm{Aa}$ & $22.38 \mathrm{Aa}$ & & \\
\hline $\mathrm{T} 3$ & $19.62 \mathrm{Aa}$ & $20.65 \mathrm{Aa}$ & $21.25 \mathrm{Aa}$ & $21.25 \mathrm{Aa}$ & & \\
\hline
\end{tabular}

Split application of phosphorus T1: $100 \%$ of the total dose at sowing; T2: $50 \%$ of the total dose at sowing plus 50\% in coating in stage V3; T3: 50\% of the total dose at sowing plus $25 \%$ in coating in stage V3 plus $25 \%$ in stage $\mathrm{C} 1$.

Seed coating: $\mathrm{C} 1$ - without coating and $\mathrm{C} 2$ - with coating.

Within each phosphorus dose, the means followed by the same letter, lowercase in the row and uppercase in the column, do not differ by the F-test $(P \leq 0.05)$ and Tukey's test $(P \leq 0.05)$, respectively.

Alternatives to increase yield and the absorption of phosphate fertilizers (location, granulation and the use of sources of lower solubility) have greater effects on soil conditions with a higher phosphorus capacity factor and low availability of phosphorus (Horowitz and Meurer, 2003; Büll et al., 2004; Prochnow et al., 2006). In a study on the performance of soybean seeds coated with phosphorus at different doses of phosphorus, it was found that coating soybean seeds with phosphorus increased yield by $14 \%$ with the use of 21 g. $\mathrm{kg}^{-1}$ of seeds coated with phytic acid (Peske et al., 2009). In addition, yield increase in plants from seeds with high concentrations of phosphorus, both endogenously and exogenously, would be attributed to the greater growth of roots and shoots and favoring nodulation (Teixeira et al., 1999; Lopes, 2001; Rose et al., 2010).

Coating seeds with phosphorus and its split application of phosphorus during the crop development stage may be feasible in order to minimize the possible problems related to the nutrient, especially in relation to its adsorption in the soils cultivated with soybeans in Brazil. Thus, higher yields for the same dose of phosphorus or smaller doses of phosphorus for currently obtained yields can be achieved.

\section{Conclusions}

Increasing the dose of phosphorus in the soil is related to increased nodulation, growth and yield components of soybean plants.
Coating seeds with monosodium phosphate at a dose of 7.0 g. $\mathrm{kg}^{-1}$ of seeds, along with split application of phosphorus, being $50 \%$ of the total dose in sowing plus $50 \%$ in coating in stage V3, significantly increases nodulation, plants growth and total seed mass per plant, especially in conditions of low doses of phosphorus in the soil.

Split application of phosphorus applied to the soil, combined with seeds coating in order to supply the nutrient in a localized way and readily available to the plant is indicated to increase soybean yield components.

\section{References}

ALMEIDA, J.P.F.; HARTWIG, U.A.; FREHNER, M.; NOSBERGER, J.; LUSCHER, A. Evidence that $\mathrm{P}$ deficiency induces $\mathrm{N}$ feedback regulation of symbiotic $\mathrm{N}_{2}$ fixation in white clover (Trifolium repens L.). Journal of Experimental Botany, v.51, n.348, p.1289-1297, 2006. http://jxb. oxfordjournals.org/content/51/348/1289.long

AQUINO, L.A.; BERGER, P.G.; OLIVEIRA, R.A.; NEVES, J.C.L.; LIMA, T.C.; BATISTA, C.H. Parcelamento do fertilizante fosfatado no algodoeiro em sistema de cultivo irrigado e de sequeiro. Revista Brasileira de Engenharia Agricola e Ambiental, v.15, n.5, p.463-470, 2011. http://www.scielo.br/ scielo.php?script=sci_arttext\&pid=S1415-43662011000500005\&lng=en\&n $\mathrm{rm}=$ iso\&tlng $=\mathrm{pt}$

BARBOSA FILHO, M.P.; FAGERIA, N.K.; SILVA, O.F. Fontes, doses e parcelamento da adubação nitrogenada em cobertura para feijoeiro comum irrigado. Ciência e Agrotecnologia, v.29, n.1, p.69-76, 2005. http://www. scielo.br/scielo.php?pid=S1413-70542005000100008\&script=sci_arttext 
BROCH, D.L.; RANNO, S.K. Fertilidade do solo, adubação e nutrição da cultura da soja. Tecnologia e Produção: Soja e Milho 2008/2009. Fundação Mato Grosso, 2008, 27p. http://www.diadecampo.com.br/arquivos/ materias/\%7B9A4E599D-3F4F-44E5-8D02-D1A25E023F03\%7D 02 fertilidade_do_solo_cultura_da_soja.pdf. Acesso em 20 de set. 2013.

BÜLL, L.T.; COSTA, M.C.G.; NOVELlO, A.; FERNANDES, D.M.; BÔAS, R.L.V. Doses and forms of application of phosphorus in vernalized garlic. Scientia Agricola, v.61, n.5, p.516-521, 2004. http://www.scielo.br/ scielo.php?script=sci_arttext\&pid=S0103-90162004000500009

CHMELIKOVA, L.; HEJCMAN, M. Effect of nitrogen, phosphorus and potassium availability on emergence, nodulation and growth of acidicole Trifolium arvense L. in alkaline soil. Flora, v.207, p.805-811, 2012. http:// www.sciencedirect.com/science/article/pii/S0367253012001387

DORDAS, C. Dry matter, nitrogen and phosphorus accumulation, partitioning and remobilization as affected by $\mathrm{N}$ and $\mathrm{P}$ fertilization and source-sink relations. European Journal of Agronomy, v.30, n.2, p.129-139, 2009. http:// www.sciencedirect.com/science/article/pii/S1161030108000932

DORSCH, J.A.; COOK, A.; YOUNG, K.A.; ANDERSON, J.M.; BAUMAN, A.T.; VOLKMANN, C.J.; MURTHY, P.P.N.; RABOY, V. Seed phosphorus and inositol phosphate phenotype of barley low phytic acid genotypes. Phytochemistry, v.62, n.5, p.691-706, 2003. http://www.sciencedirect.com/ science/article/pii/S0031942202006106

GRANT, C.A.; FLATEM, D.N.; TOMASIEWICZ, D.J.; SHEPPARD, S.C. The importance of early season phosphorus nutrition. Canadian Journal of Plant Science, v.81, n.2, p.211-224, 2001. http://pubs.aic.ca/doi/abs/10.4141/P00-093

HOROWITZ, N.; MEURER, E.J. Eficiência de dois fosfatos naturais farelados em função do tamanho da partícula. Ciência Rural, v.33, n.1, p.41-47, 2003. http:// www.scielo.br/scielo.php?script=sci_arttext\&pid=S0103-84782003000100007

KER, J.C.; FONTES, M.P.F.; SOUZA, A.R.; RESENDE, M. Adsorção de fósforo em alguns solos latossólicos: relação entre mineralogia e efeito da calagem. Revista Ceres, v.43, n.246, p.216-226, 1996.http://www.ceres.ufv. br/ojs/index.php/ceres/article/view/2317

LOPES, A.S. Boletim Técnico de Pesquisa de Soja. Rondonópolis: Fundação MT, 2001. $144 \mathrm{p}$

MALAVOLTA, E.; VITTI, G.C.; OLIVEIRA, S.A. Avaliação do estado nutricional das plantas; princípios e aplicações. 2. ed. Piracicaba: Potafos, 1997. $319 \mathrm{p}$

MEIS, S.J.; FEHR, W.R.; SCHNEBLY, S.R. Seed source effect on field emergence of soybean lines with reduced phytate and raffinose saccharides. Crop Science, v.43, n.4, p.1336-1339, 2003. https://dl.sciencesocieties.org/ publications/cs/abstracts/43/4/1336

NICO, M.; RIBAUDO, C.M.; GORI, J.I.; CANTORE, M.L.; CURA, J.A. Uptake of phosphate and promotion of vegetative growth in glucose-exuding rice plants (Oryza sativa) inoculated with plant growth-promoting bacteria. Applied Soil Ecology, v.61, p.190-195, 2012. http://www.sciencedirect.com/ science/article/pii/S0929139311002551

OLIVEIRA, P.P.A.; TRIVELIN, P.C.O.; OLIVEIRA, W.S. Eficiência da fertilização nitrogenada com ureia $\left({ }^{15} \mathrm{~N}\right) \mathrm{em}$ Brachiaria brizantha $\mathrm{cv}$. Marandu associada ao parcelamento de superfosfato simples e cloreto de potássio. Revista Brasileira de Ciência do Solo, v.27, n.4, p.613-620, 2003. http://www. scielo.br/scielo.php?pid=S0100-06832003000400005\&script=sci arttext
PACHECO, R.S.; BRITO, L.F.; STRALIOTTO, R.; PÉREZ, D.V.; ARAÚJO, A.P. Seeds enriched with phosphorus and molybdenum as a strategy for improving grain yield of common bean crop. Field Crops Research, v.136, p.97-106, 2012. http://www.sciencedirect.com/science/article/pii/ S037842901200247X

PESKE, F.B.; BAUDET, L.; PESKE, S.T. Produtividade de plantas de soja provenientes de sementes tratadas com fósforo. Revista Brasileira de Sementes, v.31 n.1, p.35-46, 2009. http://www.scielo.br/scielo. php?pid=S0101-31222009000100011\&script=sci_arttext

PROCHNOW, L.I.; QUISPE, J.F.S.; FRANCISCO, E.A.B.; BRAGA, G. Effectiveness of phosphate fertilizers of different water solubilities in relation to soil phosphorus adsorption. Scientia Agricola, v.63, n.4, p.333-340, 2006. http://www.scielo.br/scielo.php?script=sci arttext\&pid=S0103-90162006000400004

RESENDE, A.V.; FURTINI NETO, A.E.; ALVES, V.M.C.; MUNIZ, J.A.; CURI, N.; LAGO, F.J. Resposta do milho a fontes e modos de aplicação de fósforo durante três cultivos sucessivos em solo da região do Cerrado. Ciência e Agrotecnologia, v.30, n.3, p.458-466, 2006a. http://www.scielo.br/ scielo.php?pid=S1413-70542006000300011\&script=sci_arttext

RESENDE, A.V.; FURTINI NETO, A.E.; ALVES, V.M.C.; MUNIZ, J.A.; CURI, N.; FAQUIN, V.; KIMPARA, D.I.; SANTOS, J.Z.L.; CARNEIRO, L.F. Fontes e modos de aplicação de fósforo para o milho em solo cultivado da região do Cerrado. Revista Brasileira de Ciência do Solo, v.30, n.4, p.453466, 2006b. http://www.scielo.br/scielo.php?script=sci_arttext\&pid=S0100$06832006000300007 \& \operatorname{lng}=$ pt\&nrm $=$ iso

REZENDE, P.M.; GRIS, C.F.; CARVALHO, J.G.; GOMES, L.L.; BOTTINO, L. Adubação foliar. I. épocas de aplicação de fósforo na cultura da soja Ciência e Agrotecnologia, v.30, n.1, p.43-51, 2005. http://www.scielo.br/ scielo.php?pid $=$ S1413-70542005000600001\&script=sci_arttext

ROLIM NETO, F.C.; SCHAEFER, C.E.G.R.; COSTA, L.M.; CORRÊA, M.M.; FERNANDES FILHO, E.I.; IBRAIMO, M.M. Adsorção de fósforo, superfície específica e atributos mineralógicos em solos desenvolvidos de rochas vulcânicas do Alto Paranaíba (MG). Revista Brasileira de Ciência do Solo, v.28, n.6, p.953-964, 2004. http://www.scielo.br/scielo.php?script=sci arttext\&pid=S0100-06832004000600003

ROSE, T.J.; PARIASCA-TANAKA, J.; ROSE, M.T.; FUKUTA, Y.; WISSUWA, M. Genotypic variation in grain phosphorus concentration, and opportunities to improve P-use efficiency in rice. Field Crops Research, v.119, n.1, p.154-160, 2010. http://www.sciencedirect.com/science/article/ pii/S0378429010001735

SHAFQAT, M.N.; PIERZYNSKI, G.M. The effect of various sources and dose of phosphorus on residual soil test phosphorus in different soils. Catena, v.105, p.21-28, 2013. http://www.sciencedirect.com/science/article/pii/ S0341816213000155

SOARES, M.M.; ARAÚJO, E.F.; OLIVEIRA, G.L.; SILVA, L.J.; SORIANO, P.E. Nodulation and growth of soybean plants as a function of coating the seeds with phosphorous. Bioscience Journal, v.30, n.5, p.1438-1446, 2014 http://www.seer.ufu.br/index.php/biosciencejournal/article/view/21862

SOUZA, F.S; FARINELLI, R.; ROSOLEM, C.A. Desenvolvimento radicular do algodoeiro em resposta à localização do fertilizante. Revista Brasileira de Ciencia do Solo, v.31, n.2, p.387-392, 2007. http://www.scielo.br/scielo. php?pid=S0100-06832007000200021\&script=sci_arttext

TEIXEIRA, K.R.S.; MARIN, V.A.; BALDANI, J.I. Nitrogenase: bioquimica do processo de FBN. Seropédica: Embrapa Agrobiologia, 1999. 25p. 
ThaVARAJAH, D.; THAVARAJAH, P.; SEE, C.; VANDENBERG, A.; Phytic acid and $\mathrm{Fe}$ and $\mathrm{Zn}$ concentration in lentil (Lens culinaris L.) seeds is influenced by temperature during seed filling period. Food Chemistry, v.122, n.1, p.254-259, 2010. http://www.sciencedirect.com/science/article/ pii/S0308814610002578

TRIGO, L.F.N.; PESKE, S.T.; GASTAL, M.F.; VAHL, L.C.; TRIGO, M.F. $\mathrm{O}$ efeito do conteúdo de fósforo na semente de soja sobre o rendimento da planta subsequente. Revista Brasileira de Sementes, v.19, n.1, p.111-115, 1997. http://www.abrates.org.br/revista/artigos/1997/v19n1/artigo21.pdf
VANCE, C.P.; UHDE-STONE, C.; ALLEN, D.L. Phosphorus acquisition and use: Critical adaptations by plants for securing a nonrenewable resource. New Phytologist, v.157, n.3, p.423-447, 2003. http://onlinelibrary.wiley.com/ doi/10.1046/j.1469-8137.2003.00695.x/full 